\title{
維持·補修を考慮に入れた橋梁の ライフサイクルコストの評価について
}

\author{
信州大学大学院 ○高澤 和典 ${ }^{*}$ \\ 株式会社 大林組多田 栄一** \\ 信州大学 小山 健 ${ }^{*}$ \\ by Kazunori Takasawa, Eiichi Tada and Ken Koyama
}

我が国では，高度成長期に建設された土木構造物が，主として経済的または社会的 な耐用年数の終わりに近くなっている現状であると考えられさまざまな維持管理およ び補修計画が必要になってきている。したがって，適切な維持管理および補修計画・ 対策がコスト・マネジメントの観点および資源とエネルギーの節約または社会資本の 適正管理といった面から、今後とも重要な問題になるように思われる。

本研究は, これらの観点から, 土木構造物のなかでも, 特に橋梁構造物を対象として, 一般に橋梁に必要とされている耐用年数間にかかる維持・補修に関するライフサイク ル・コストの評価に関して, シミュレーションモデルを作成し, 維持管理・補修計画 に対する定性的な経済性比較を行った。

【キーワード】 補修計画, ライフサイクルコスト, 経済性評価

\section{1 、まえがき}

現在，多くの土木構造物において損傷の発生が報 告され(1)，それに伴う維持, 補修費も増加の一途を たどっている。一方，高度成長期に比べて新設構造 物の整備速度が低くなった現状においては，既設構 造物を維持, 補修 ${ }^{2) ~ 8)}$ によって出来るだけ長期にわ たって使用することが重要なことと考えられる。こ のためには，構造物の寿命，つまり構造物が現在ど のような状態におかれていて，今後，どのような状 態へ変化していくのかを正確に把握することが不可 欠である。また，日本は降雨や降雪が多く，しかも 世界的に有数の地震国であるため, 取り替え, 補修 を行う必要のある土木構造物が絶えず発生してくる。 3)このような問題点について本研究は, 数ある土木

$\begin{array}{ll}{ }^{*} \text { 工学部社会開発工学科 } & T e 1: 0262(26) 4101 \\ { }^{* *} \text { 株式会社 大林組 } & \mathrm{Tel}: 0762(78) 7040\end{array}$

構造物の中から特に橋梁に対して，その取り替え (Replacement) と補修 (Rehabilitation) のシミ エレーションを設定してその経済性評価を行い，今後 の補修（維持，管理）業務の政策を考えていくもの である。

\section{2.土木構造物の経済性の評価方法}

一般に，土木構造物の耐用期間における経済性を 評価するためには異なる時点における収益や費用を 同一の時点での価値に換算して比較することが必要 で, ${ }^{9}$ 開発期間や耐用期間が異なるいくつかの代替案 の評価の比較に用いられる。（表-1, 図-1 参照）

本研究ではその評価方法として以下のような代替 案の比較によって行うことにした。101

（1）いつかは取り替えを行う既設構造物の余儀な き理由による (Force Account) 補修

（2）いつかは取り替えを行う既設構造物の契約 


\section{表 -1 基本的価値換算係数}

\begin{tabular}{|c|c|}
\hline 価値換算係数 & 式 \\
\hline 現価係数 & $(P / F, i, n)=(1+i)^{-n}$ \\
\hline 資本回収係数 & $(A / P, i, n)=i(1+i)^{\mathrm{n}} /\left\{(1+i)^{\mathrm{n}}-1\right\}$ \\
\hline
\end{tabular}

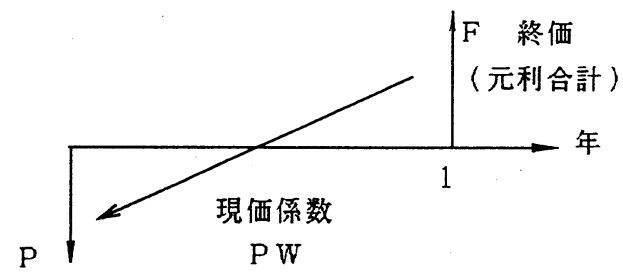

現価

(投資)

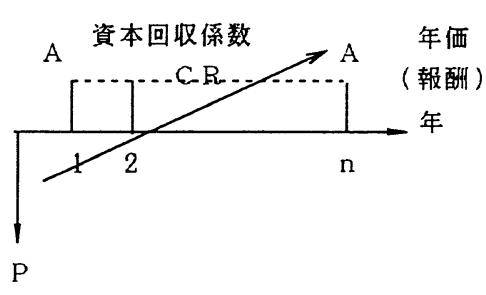

現価

(投資)

図-1 価値換算係数の関係図

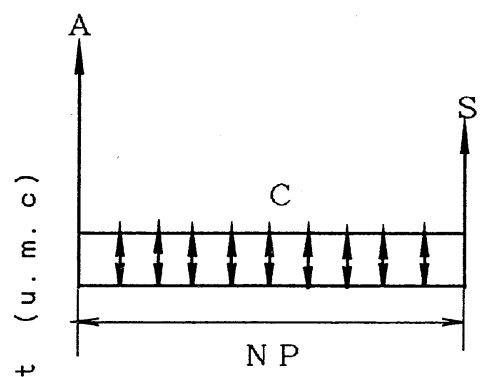

(a) Replacement Model

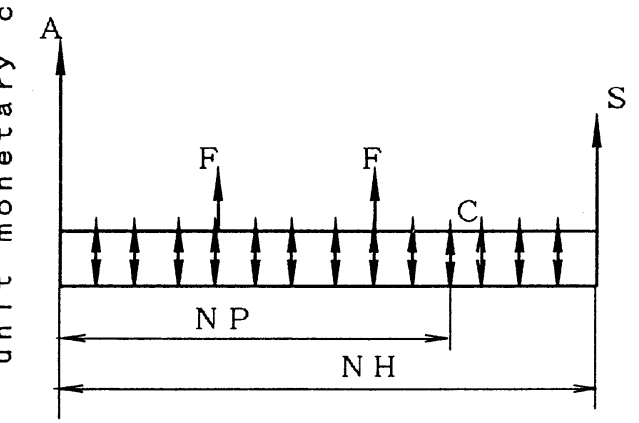

(b) Rehabilitation Model

図-2 資金流れ図

(Contract) による補修

（3）直ちに行う構造物の取り替え

(1)と（2）は，補修の代替案で，最終的な取り替えを 含んでいる。（3）は，取り替えの代替案で, (1)と (2)
に入力するパラメーターであるために最初に評価を 行う。つまり(1)と (2)の補修の代替案を比較評価し て費用の安い方を(3)の取り替えの代替案と比較する。 ただし，本研究では，(1)と(2)の区別はしないむの とし, 取り替え, 補修の代替案の比較之評価は, 次 のようなVM値 (Value Management Term) ${ }^{10)}$ によっ て行う。

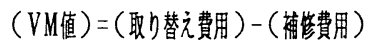

本研究では，このVM值がその土木構造物を取り替 えるべきか，補修するべきかを判断する比較指標之 なる。具体的には，(VM值)>0の上きは取り替之費用の 方が高いので，その既設構造物の維持, 補修をした 方が有利だと言うことになり，逆に，(VM值)<0のとき は，補修費用の方が高いので，その既設構造物に見 切りをつけて新しく構造物を建設した方が有利だと いうことになる。

次に土木構造物の耐用期間において補修業務にか かる費用を，毎年均等に返済すると仮定した場合の 単年における費用 (Life Cycle Cost) のことをEUAC (Equivalent Uniform Annual Cost) と定義する。 ${ }^{10)}$ 本研究で対象とする経済性評価モデルとして, 取 り替え (Replacement) と補修 (Rehabilitation)の 2 通りの代替案と資金流れ図を图一2に示した。 この図で用いられている記号は以下のようである。 


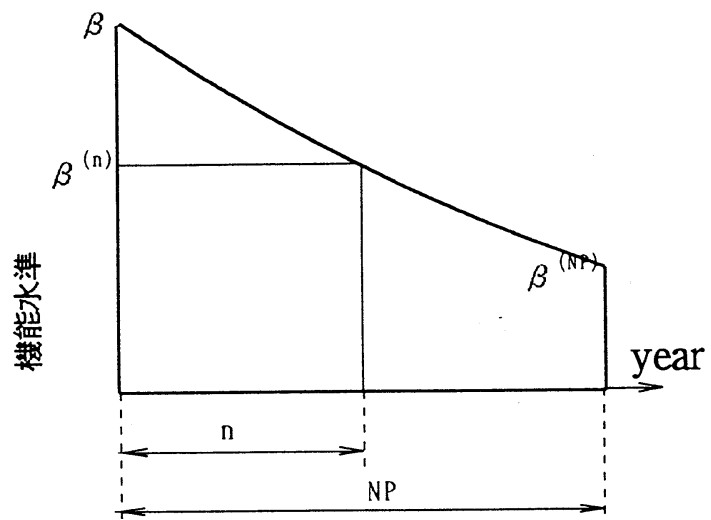

(a) TYPE 1

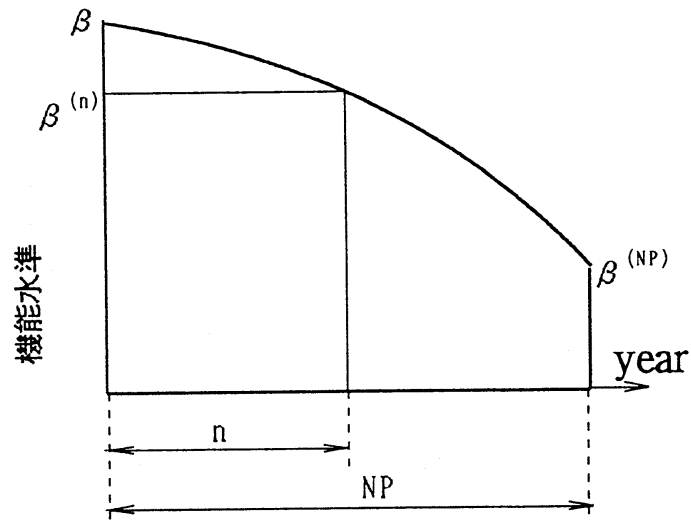

(b) TYPE 2

図 - 3 構造物の劣化状況パターン

A ：建設時の初期費用

S：撤去費用

F : 不定期に生ずる補修費用

C : 毎年必要な維持, 管理費用

（清掃，塗装など）

$\mathrm{NP} \quad$ : 構造物の耐用年数

$\mathrm{NH}$ ：補修によって維持できる年数

3. シミュレーションモデルの設定

構造物は，建設時から時間の経過とともに劣化が 始まる。また, 劣化の状況も様々なパターンがある。 ${ }^{8)}$ その劣化の状況を数值仮定することにより機能水準 を考虑した評価を行うことにした。

本研究では, 図ー 3 のような 2 種類の劣化パター ンを仮定して評価していく。2 種類の劣化とは，建 設後すぐに劣化が始まる夕イプと建設後何年か後に 急に劣化が始まるタイプである。前者をTYPE1として 式(2), 後者をTYPE2として式(3)で表す。建設時点の 土木構造物の機能水準を $\beta$, 建設時から $\mathrm{n}$ 年後の機 能水準を $\beta^{(n)}$ として次のような式を仮定する。

$\beta^{(n)}=\beta \cdot \exp (-a \cdot n / N P)$

$\beta^{(n)}=\beta \cdot\left(11-\exp \left(a^{\prime} \cdot n / N P\right)\right) / 10$

ここで, $\mathrm{n}$ : 経過年数, $\alpha, \alpha^{\prime}$ : 定数，である。 本研究では, 式(2)において $\alpha=0.5^{11)}$ として計算 を行った。このとき, $\beta^{(\mathrm{NP})}=0.607 \beta$ である。この $\beta^{(N P)}$ がほぼ等しくなるように式( 3 )で $\alpha$ 'を求める
と, $\alpha^{\prime}=1.6$ となる。これらの機能水準に基づいて次 の 2 つ方法で比較していくことにする。

（1）橋を建設して耐用年数がきたらそのまま撤去 する。

$\left(\mathrm{EUAC}_{\mathrm{REP}}\right)$

（2）橋の補修をして少しでも長持ちさせる。

$\left(\mathrm{EUAC}_{\mathrm{REH}}\right)$

いま（VM值）をEUACを用いて表すと次式のように なる。

$(V M$ 值 $)=(E U A C)_{R E P}-(E U A C)_{R E H}$

4. シミュレーションモデルの条件

3.で設定したシミコレーションモデルには多くの 変数が用いられ，その変数は予測，予期されにくい。 また，補修を行う時期も予測しにくい。そこで橋梁 の故障の分布がポアソン分布に従うとき, 故障時間 の分布は指数分布に従うことを用いて疑似乱数を発 生させて疑似状況を仮定することによって計算する ことにした。そのためこの状況は，それぞれのシミ エレーションのみ妥当であって現実の問題とは多少か け離れてしまう可能性を多分に含んでいるが, 本研 究では, 次に述べるような值を用いて計算を行いそ の違いにより結果にどのような影響を及ぼすのかを 定性的に調べていくことにする。

（1）利率 i について 
補修費增加曲線
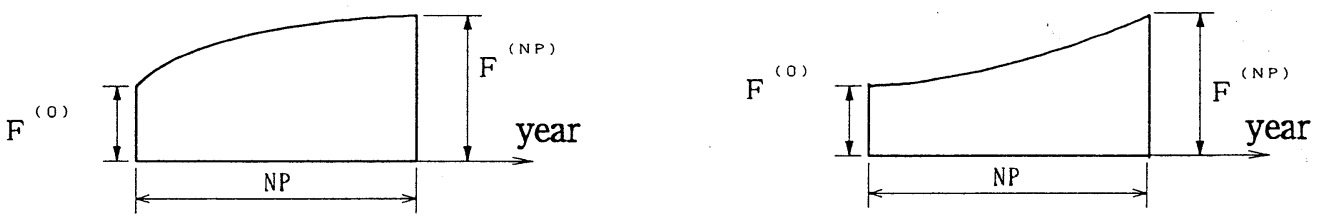

回復率減少曲楾

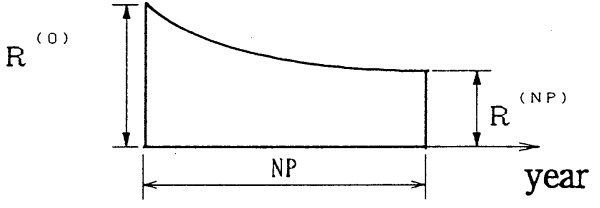

(a) TYPE 1

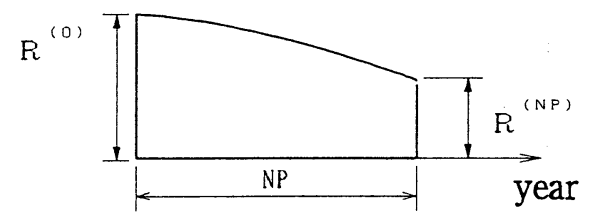

(b) TYPE 2

図-4 補修の費用, 回復率の変化

あまり大幅な金利の上昇（インフレーション）が 見込まれることは，考えないことにして，利率 $\mathrm{i}=0$. 03 0.07 の範囲で考えることにする。

\section{（2）費用について}

土木構造物の規模などにより多種多様にある費用 額の定量的な扱いは避けて, 初期費用Aを基準とし， その他の費用は $A=1$ に対しての比で表すこととし, 以 下の上うに仮定した。これは, 結果の理解を容易に するためである。

初期費用 $: A=1.0$

撤去費用 $: S=0.5$

毎年必要な維持管理費用 $\quad: C=0.02$

\section{(3) 耐用年数}

土木構造物の特にコンクリート橋における耐用年 数は, 大蔵省令による法定的耐用年数によると，一 般に 40 50年と考えられるので，本研究では耐用年数 NPとして大まかに40 80年程度と考えた。4

\section{（4）不定期に生ずる補修を行う年数の発生}

予想しにくい補修を行う年数は, 疑似乱数を発生 させ指数分布を用いて決定する。そのときの期待値 (AVK)はAVK =10,20として計算を行う。AVK=10とは， 10 年に 1 度比較的大規模な補修を行うということ
を意味する。

（５）不定期に生ずる補修費用之機能水準の回復率 橋梁の補修について考えると橋の長い一生におい て, 補修に関する費用, 回復率は変化していくもの だと考えられる。橋の劣化の進んでいない早い時期 に補修すれば，補修費は少なくて済むであろうし， また劣化の進んだ遅くには多くを必要とするであろ う。回復率についていえば, 劣化の進んでいない早 い時期には補修をすれば，高い回復率が期待できる であろうし, 劣化の進んだ遅くでは低い回復率しか 期待できないであろう。このように補修に関する費 用, 回復率は, 補修を行う時期によって変わってく ると考えられる。このことを踏まえてシュミレーシ ヨンを行う。2 種類の劣化の夕イプのそれぞれの補 修の費用, 回復率の変化を図ー4にのせた。

建設まもなく補修をしたときの補修費，回復率を， $\mathrm{F}^{(0)}, \mathrm{R}^{(0)}, \mathrm{N}$ 年たったときに補修をしたときの補修費， 回復率を, $\mathrm{F}^{(\mathrm{N})}, \mathrm{R}^{(\mathrm{N})}$ とするとTYPE1, TYPE2での補修 郿増加曲線, 回復率隇少曲線を表す式は以下のよう になる。 TYPE 1:

$$
\begin{aligned}
& R^{(n)}=R^{(0)} \cdot \exp \left(-\ln \left(R^{(0)} / R^{(N P)}\right) \cdot n / N P\right) \\
& F^{(n)}=F^{(0)} \cdot\left(9+\operatorname{EXP}\left(\ln \left(10 \cdot F^{(N P)} / F^{(0)}\right) \cdot n / N P\right) / 10\right.
\end{aligned}
$$



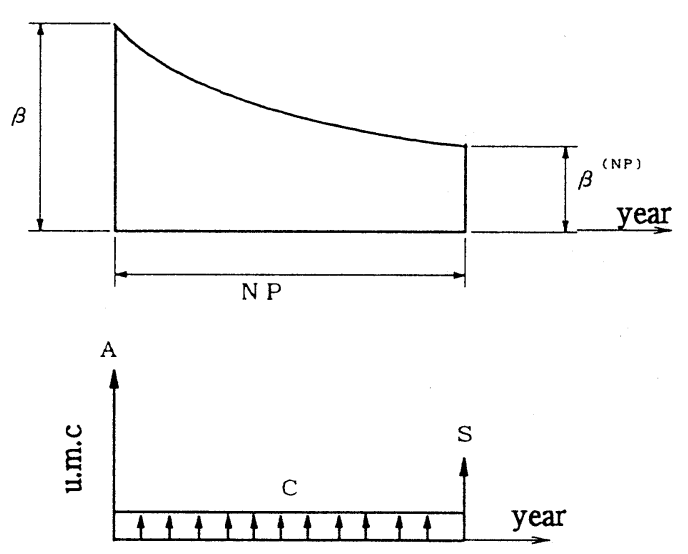

(a) TYPE1
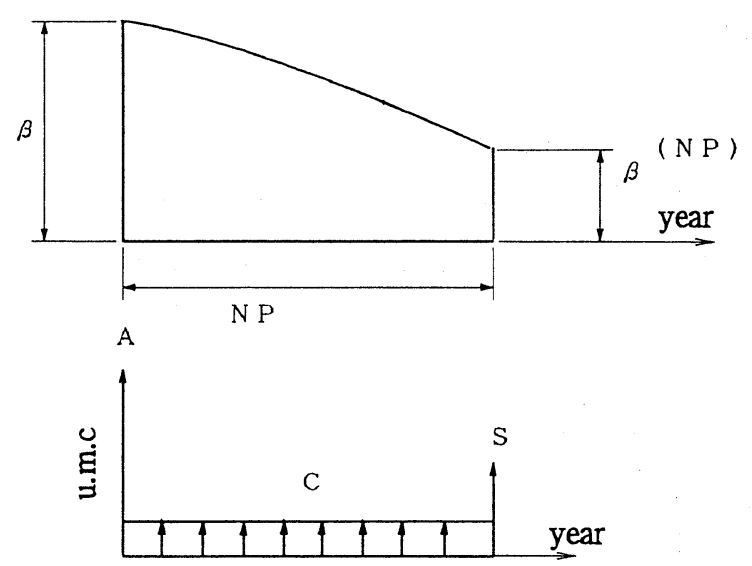

(b) TYPE2

図 -5 資金流机図之橋梁の劣化状況図

TYPE 2:

$$
\begin{aligned}
& R^{(n)}=R^{(0)} \cdot\left(11-\exp \left(\ln \left(11-10 \cdot R^{(N P)} / R^{(0)}\right) \cdot n / N P\right)\right) \\
& / 10 \\
& F^{(n)}=F^{(0)} \cdot \exp \left(\ln \left(F^{(N P)} / F^{(0)}\right) \cdot n / N P\right)
\end{aligned}
$$

補修モテルの場合においてどの程度の補修費用 $\mathrm{F}$ をかけるかは，補修する時の補修費増加曲線に基づ いて決定するが, ここでは $\mathrm{F}^{(0)}=0.1, \mathrm{~F}^{(\mathrm{NP})}=0.1$, $0.2,0.3,0.4,0.5$ と仮定した。補修によって土木構 造物の機能水準が, 前回の補修時，または建設時に 対してどの程度まで回復できるかは事実上は不明で あるが,ここでは， $\mathrm{R}^{(0)}=100 \%$ とし $\mathrm{R}^{(\mathrm{NP})}=70 \%$ と仮定 した。

ここでいう回復率とは, 補修によって土木構造物 の機能水準が, 前回の補修時，または建設时に対し て劣化によって機能水準の值が減少した分の何\%程 度回復するかを示すものとする。

\section{5. シミュレーションモテルの計算例}

\section{（1）補修期間の発生方法 ${ }^{11}$}

橋梁の故障の分布がポアソン分布に従うと仮定す る。その場合, 故障時間の分布は指数分布に従う。 ここで，指数分布の期待值を $1 / \mathrm{k}(1 / \mathrm{k}$ 年に 1 度補修 が必要になる）とおくと, $t$ 年間で橋梁の故障が $\mathrm{x}$
回発生する確率 $\mathrm{P}(\mathrm{x})$ は,

$P(x)=\frac{(k t)^{x}}{x !} \cdot e^{-k t}$

であるので， 補修の発生年間隔を $\mathrm{t}$ とすると, $\mathrm{t}$ 年 以内に橋梁の故障が 1 度も発生しない確率は, 式 (9) でX=0とおいて,

$P(0)=e^{-k t}$

である。従ってその余事象を考えると， $\mathrm{t}$ 年以内に 橋梁の故障が起こる（補修が必要になる）というこ とであり，その確率 $\mathrm{P}^{\prime}(\mathrm{t})$ は，

$$
\begin{aligned}
P^{\prime}(\mathrm{t}) & =1-\mathrm{P}(0) \\
& =1-\mathrm{e}^{-\mathrm{k} t}
\end{aligned}
$$

これから兟求めると次のように得られる。

$\left.\mathrm{t}=-\frac{1}{\mathrm{k}} \cdot \ln (1-\mathrm{P} \cdot \mathrm{t})\right)$

ここで， $P^{\prime}(t)$ は一様乱数を発生させることにより 得られる。ただしAVK=1/kで表される。

(2) 取り替えモデル $\left(\mathrm{EUAC}_{\mathrm{REP}}\right)$

この取り替えモデルは，設計時に決めた耐用年数 NPがきたら，直ちに取り替え作業を行うモテルであ る。すなわち橋梁の機能水準が， $\beta^{(N \mathrm{P})}$ になった時 に取り替え作業を行うというモデルである。そして， 費用の面では，初期費用と撤去費用それに清掃, 塗装 などの毎年行う補修以外は費用をかけないというモ 
TYPE 1
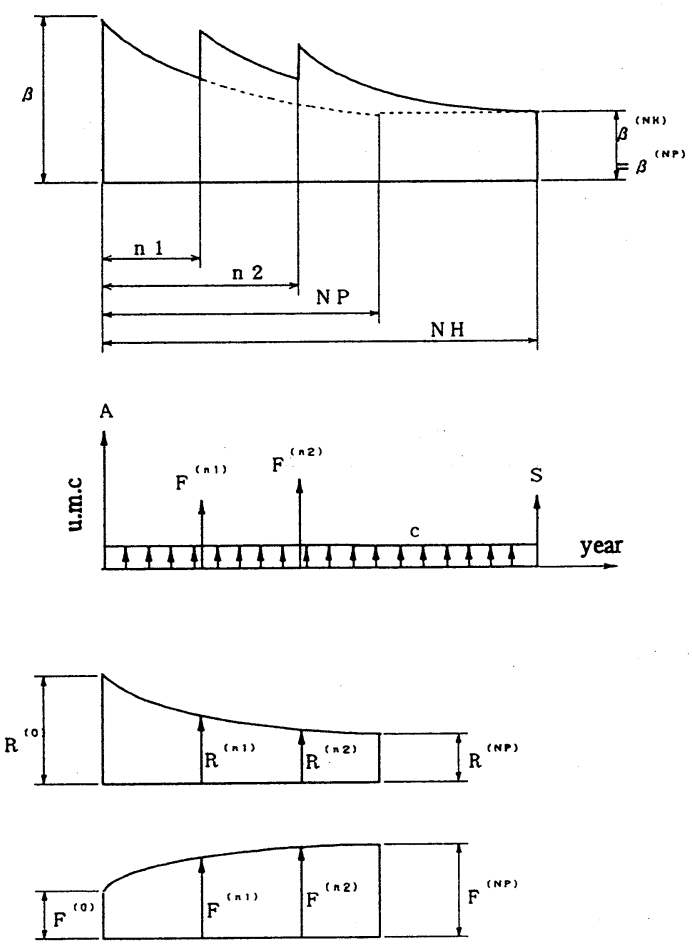

TYPE 2
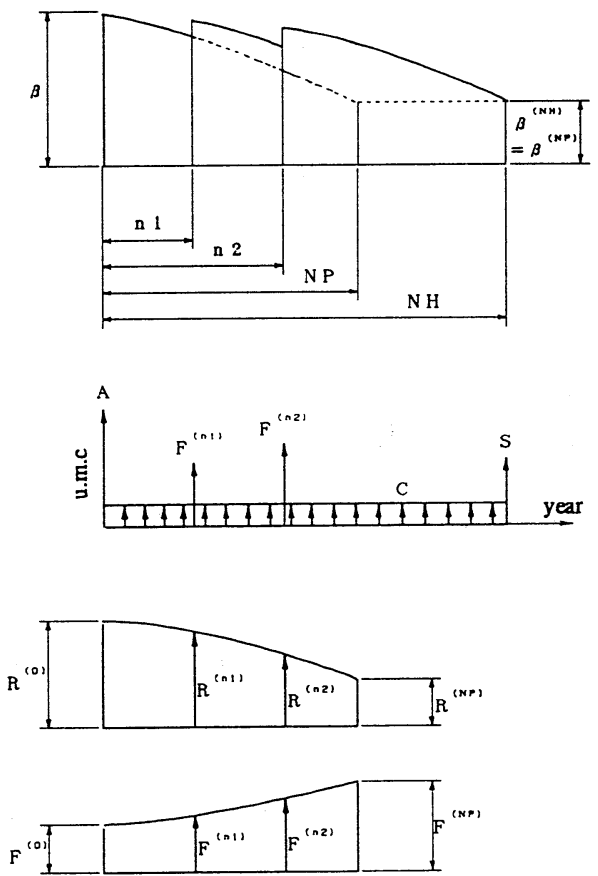

図 - 6 補修モテルの資金流れ図と橋梁の劣化状況図

デルである。

このモデルの資金流れ図と橋梁の劣化状況を,图-5

で表す。

これより，取り替えモテルのEUACを示すと次式の

ようになる。

$\operatorname{EUAC}_{R E P}=(A / P, i, N P) \times(A+S \times(P / F, i, N P))+C \cdots(15)$

(3.) 補修モデル $\left(\mathrm{EUAC}_{\mathrm{REH}}\right)$

この補修モデルは，建設時の耐用年数をNP年とし て，ni年後に補修を行うことにより機能水準を向上 させてNP年より何年かでも長く維持させようとする モデルである。このモテルでは，ni年に補修作業を 行いその時の補修費は, 補修費增加曲線で, 回復率 は, 回復率隇少曲線によって決定する。補修作業で は機能水準 $\beta^{(n i)}$ を, 回復度 $\mathrm{R}$ まで向上させる。こ の作業を何回か行いniが耐用年数NPを越えるときそ こで補修作業をやめ, 橋梁の機能水準が $\beta^{(\mathrm{NP})}$ にな ったときに撤去作業を行うとする。このモデの資
金流れ図と橋梁の劣化状況を，図-6で示す。

補修モデルのEUACを示すと次のようになる。 $\operatorname{EUAC}_{\mathrm{REH}}=(\mathrm{A} / \mathrm{P}, \mathrm{i}, \mathrm{NH}) \times(\mathrm{A}+\mathrm{S} \times(\mathrm{P} / \mathrm{F}, \mathrm{i}, \mathrm{NH})$

$$
\left.+\sum F(n i) \times(P / F, i, n i)\right)+C
$$

6. E U A C の計算例

ここでは，式(3)で表される劣化について，NP=60, $\mathrm{i}=0.04, \mathrm{~F}^{(0)}=0.1, \mathrm{~F}^{(\mathrm{NP})}=0.5, \mathrm{R}^{(0)}=100 \%, \mathrm{R}^{(\mathrm{NP})}=70 \%$, $A V K=20$ の場合の計算例を示す。橋梁の機能水準は建 設時を 1 として，1に対しての比で表した。

(1) 取り替えモテル

取り替えモデルの劣化状況図と資金流机図は龱-7 (a)(b)のようになる。このモデルにおける $\mathrm{EUAC}_{\mathrm{REP}} \mathrm{P}$ 求めると以下のようる。

$\operatorname{EUAC}_{R E P}=(A / P, 0.04,60) \times\{1+0.5 \times(P / F, 0.04,60)\}$

$+0.02=0.0663 /$ year 


\begin{tabular}{|c|c|c|c|c|c|c|}
\hline $\begin{array}{l}\text { メンテナル } \\
\text { 回数 }\end{array}$ & $\begin{array}{c}\text { メンテナンス } \\
\text { 発生間隔 } \\
\end{array}$ & $\begin{array}{l}\text { メンテナリス } \\
\text { 発生年数 }\end{array}$ & $R^{(n)}$ & $F^{(n)}$ & $\beta_{0}$ & $\beta_{1}$ \\
\hline 1 & 18 & 18 & $89.8 \%$ & 0.162 & 0.861 & 0.986 \\
\hline 2 & 24 & 42 & $77.9 \%$ & 0.309 & 0.807 & 0.946 \\
\hline 3 & 13 & 55 & $72.1 \%$ & 0.437 & 0.849 & 0.919 \\
\hline
\end{tabular}
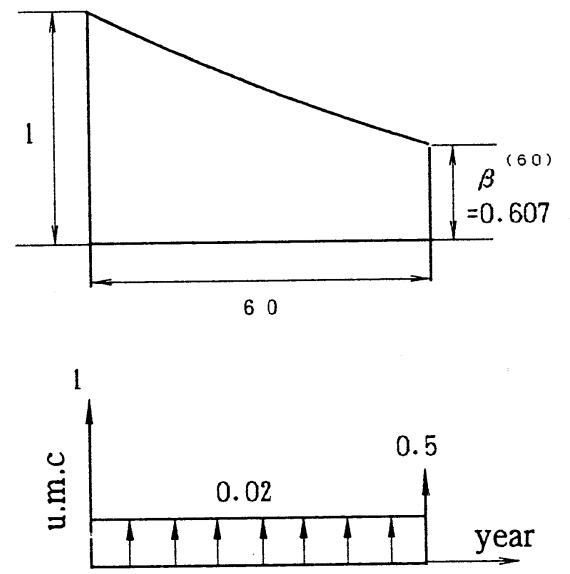

図-7 取り替えモデルの劣化状況図と資金流れ図

\section{（2）補修モデル}

取り替えモデルと同様の条件のもとで橋梁の劣化 状況図と資金流れ図と計算例を图-8，表-2で表示した。

このモテルの $\mathrm{EUAC}_{\mathrm{REH}}$ は前と同様にして以下のよう

に求められる。

$\mathrm{EUAC}_{\mathrm{REH}}=0.0688 /$ year

式 (17)，(18)よりVM倠を求めると,

$(V M$ 值 $)=E U A C_{R E P}-E U A C_{R E H}$

$$
=0.0663-0.0688=-0.0025
$$

となり，この計算例では (VM值)く0なので，取り替え のほうが安くなる。

以後, 補修モデルの場合, 乱数の発生シミュレー ションを100回行い, 得られた結果の平均值をその仮 定条件でのEUACとした。
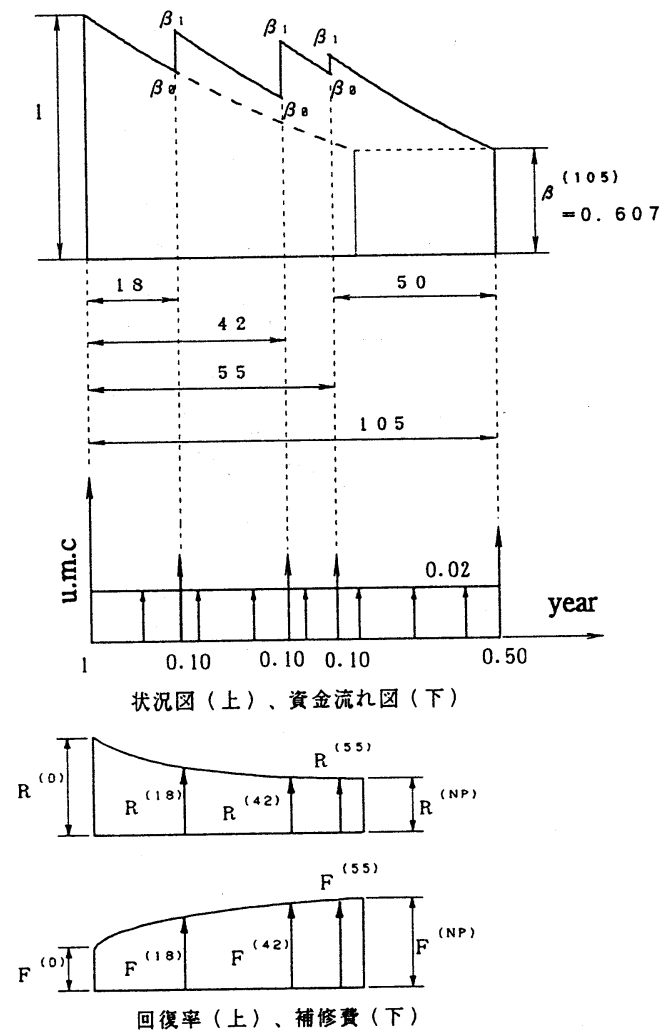

図-8 補修モデルの劣化状況図と資金流れ図

\section{7. 計算結果}

シミュレーションの計算で得られた結果を图-10お よび图-11にのせた。表-3には，各条件による補修モデ ルの寿命の平均值を示した。

团-10(a) (f)ではTYPE1の劣化パターンのEUACを, 图11(a) (f)ではTYPE2の少化パターンのEUACを示した。 


\begin{tabular}{|c|c|c|c|}
\hline & 表-3 & デルの寿命 & \\
\hline \multirow[t]{2}{*}{$\mathrm{N} \mathrm{P}$} & \multirow[t]{2}{*}{ A V K } & \multicolumn{2}{|c|}{$\mathrm{NH}$} \\
\hline & & T Y P E 1 & TY P E 2 \\
\hline \multirow[b]{2}{*}{40} & 10 & 68 & 74 \\
\hline & 20 & 64 & 69 \\
\hline \multirow[b]{2}{*}{60} & 10 & 105 & 113 \\
\hline & 20 & 100 & 108 \\
\hline \multirow[b]{2}{*}{80} & 10 & 142 & 152 \\
\hline & 20 & 136 & 149 \\
\hline
\end{tabular}

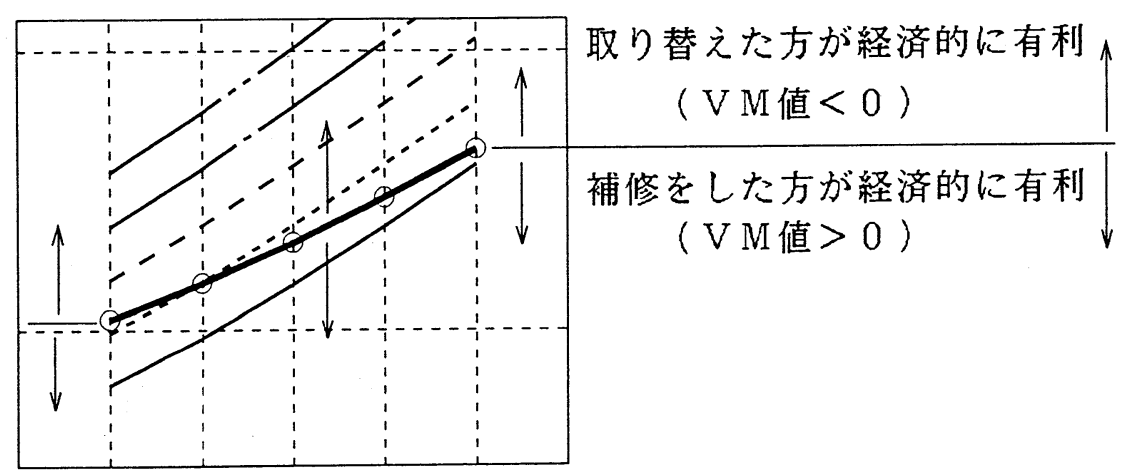

図 -9 図の見方の説明

図中では，横軸に利率，縌軸に年均等価格EUACを とり, $\mathrm{EUAC}_{\mathrm{RE}} \mathrm{P}$ を極太線と点, $\mathrm{EUAC}_{\mathrm{REH}}$ は太線で表 し，補修費用の違いは線種で区別した。

極太線が太線より上にある場合はEUAC REP $>E U A C_{R E}$ нटなりVM值>0であるので補修をした方が経済的に有 利である事を意味し, また, 逆に極太線が太線の下 にある場合は $E_{U A C} C_{R P}<E_{\text {EUAC }}$ RH 取り替えをした方が経済的に有利である事を表して いる(図-9を参照）。例えば，困-10(a)で見るとi $=0.03$ の場合には $\mathrm{F}(\mathrm{NP})=0.4$ 以上だと取り替えた方が 有利で，それ以下だと補修した方が有利であること がわかる。

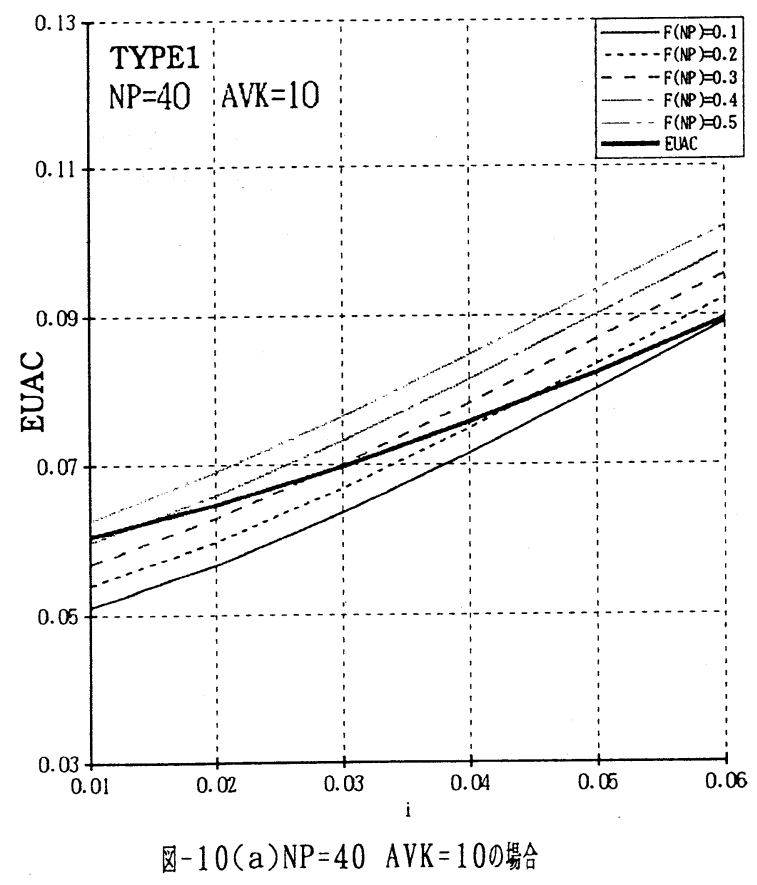




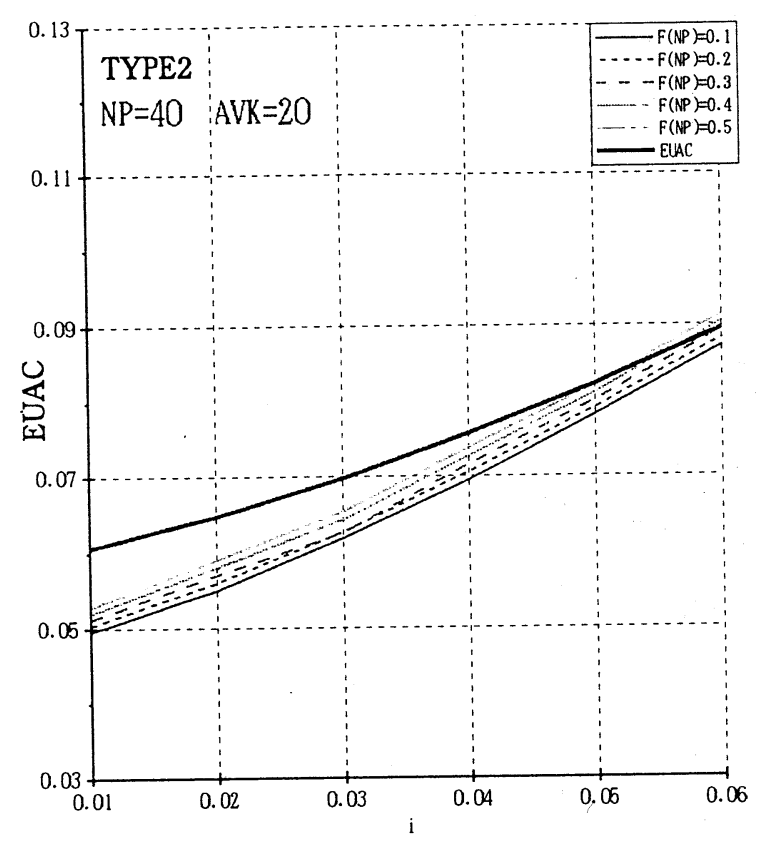

国-10(b) NP=40 AVK=200㙋合

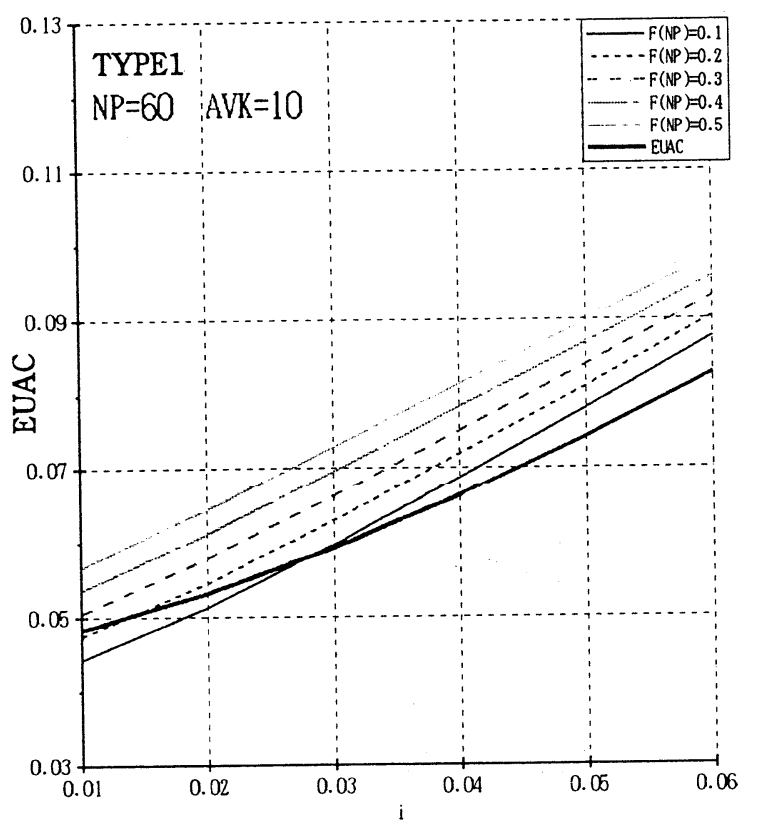

国-10（c) NP=60 AVK=100脂合

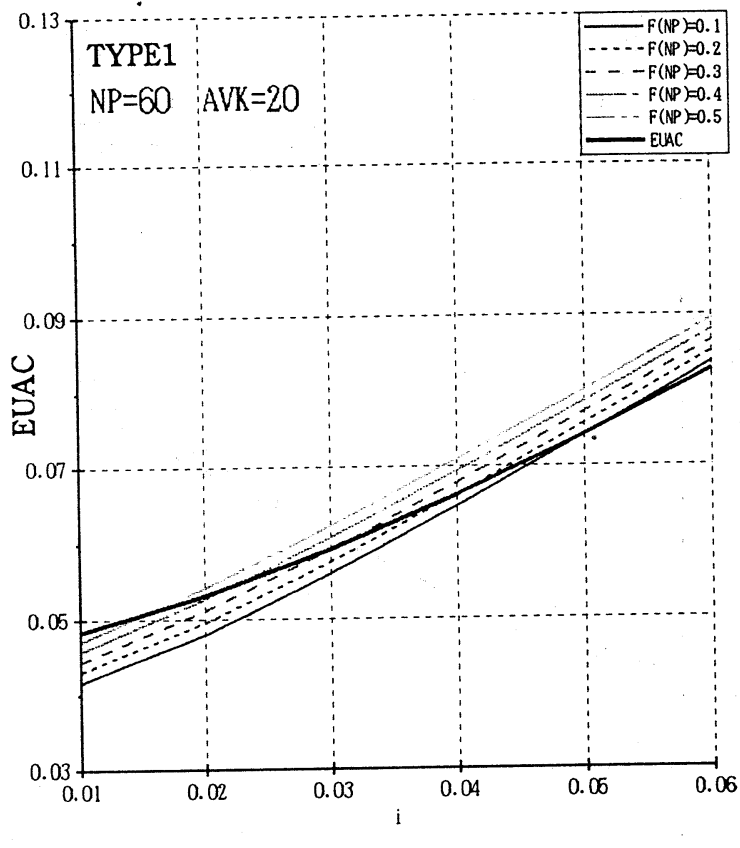

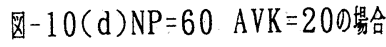

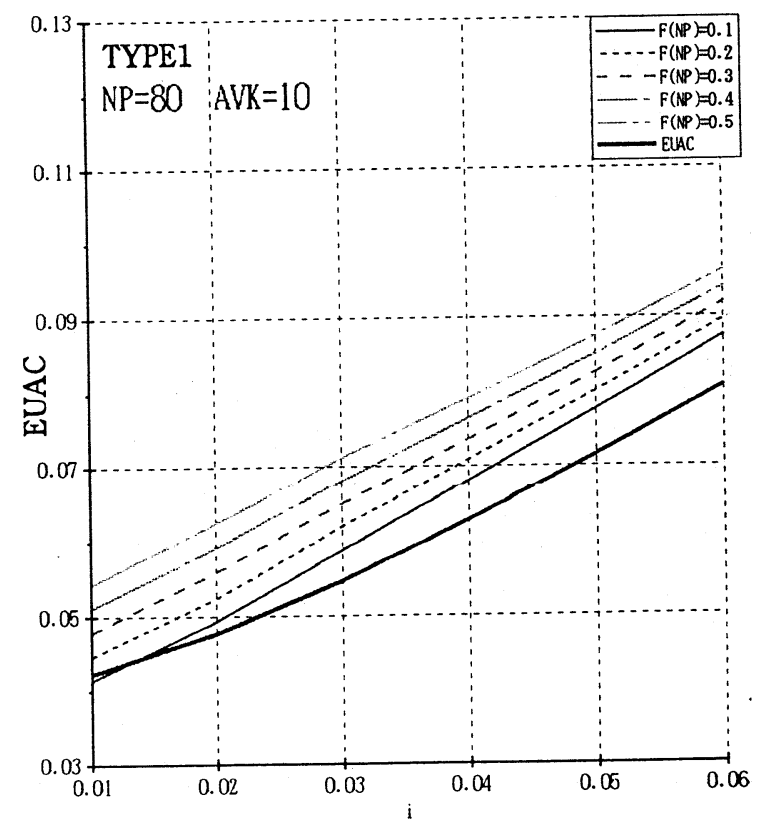

囷-10（e) NP=80 AVK=100第合 


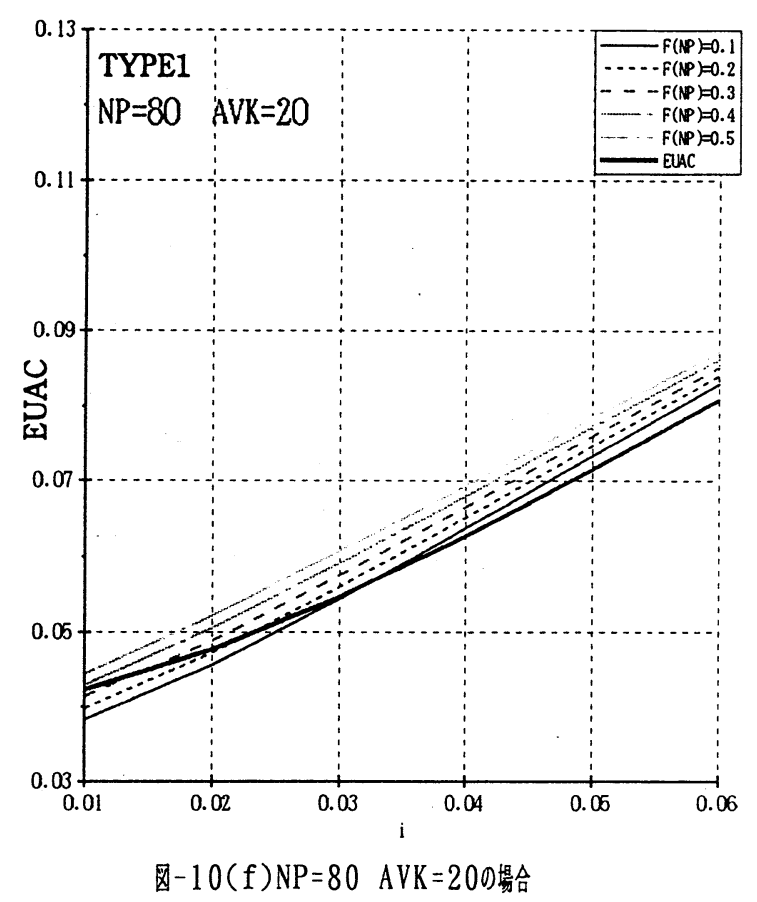

図-10 E U A C と利率の関係：T Y P E 1 の場合

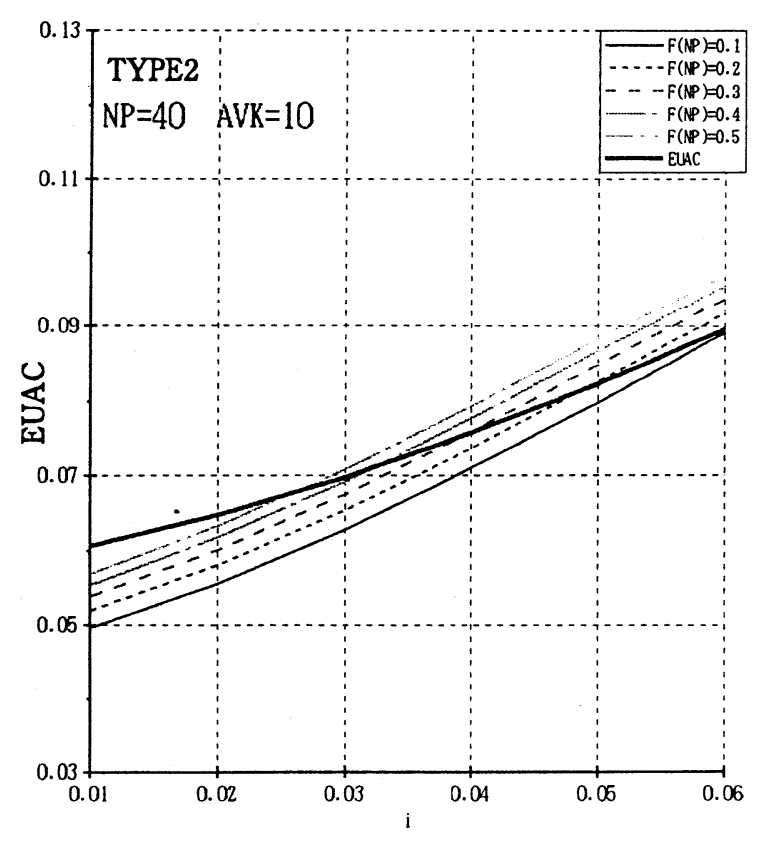

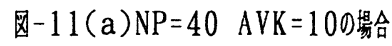
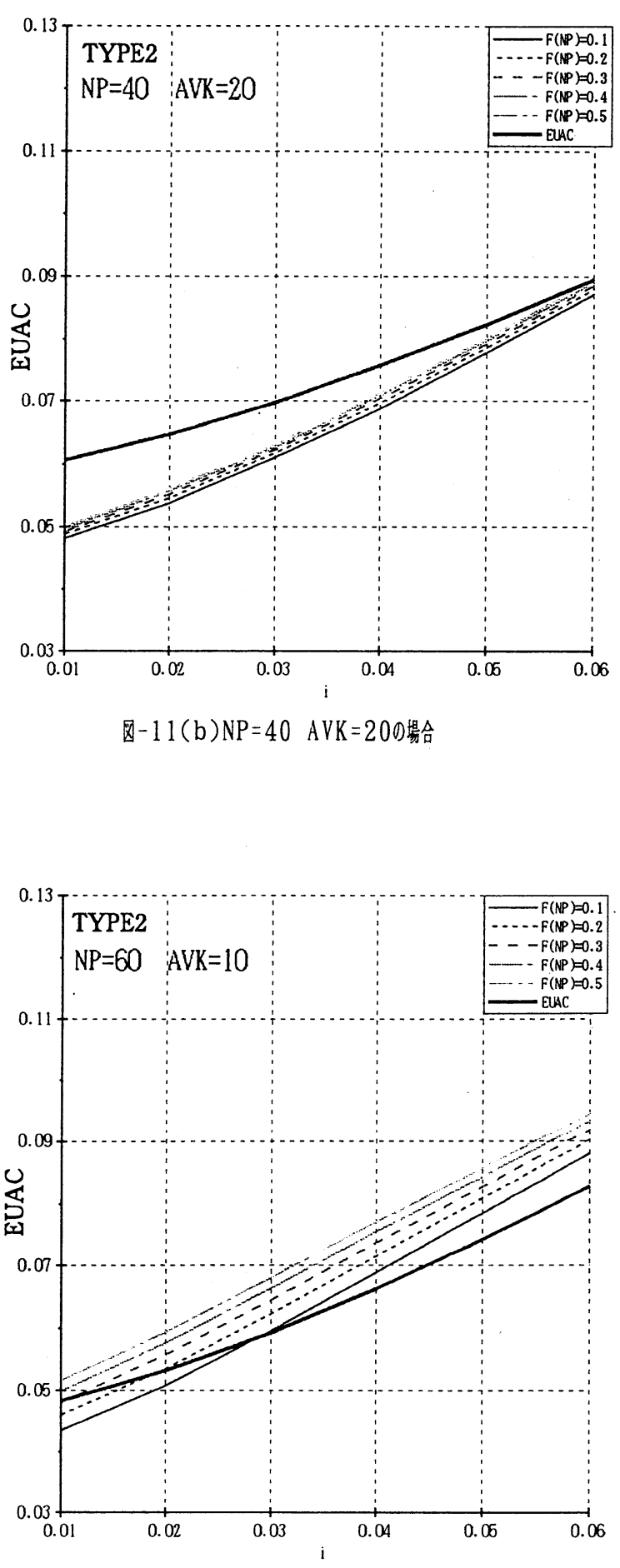

図-11(c) NP=60 AVK=100蚄合 


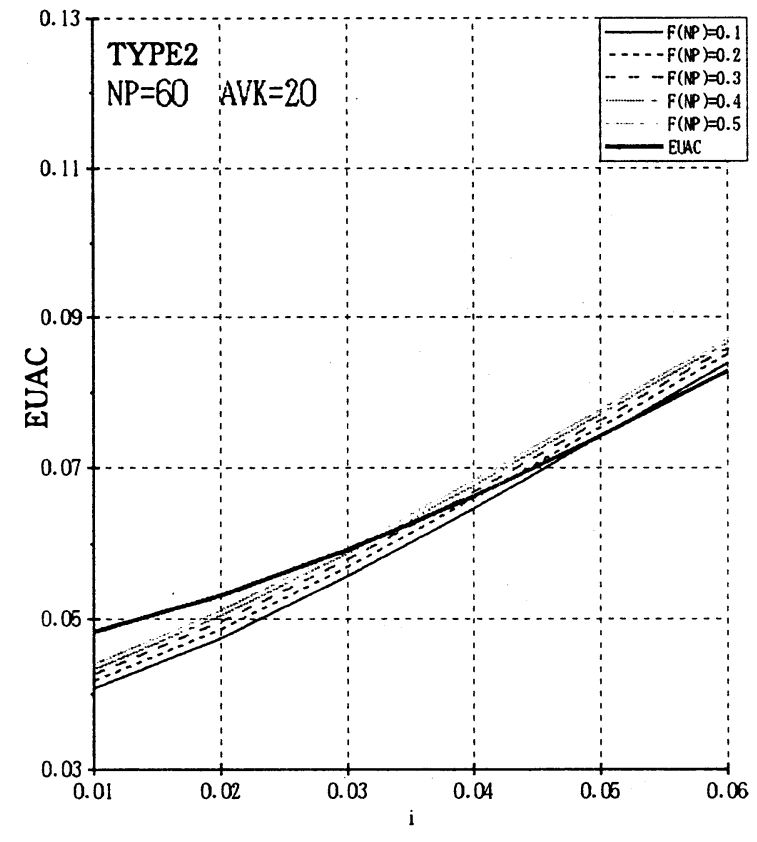

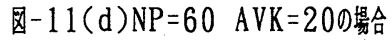

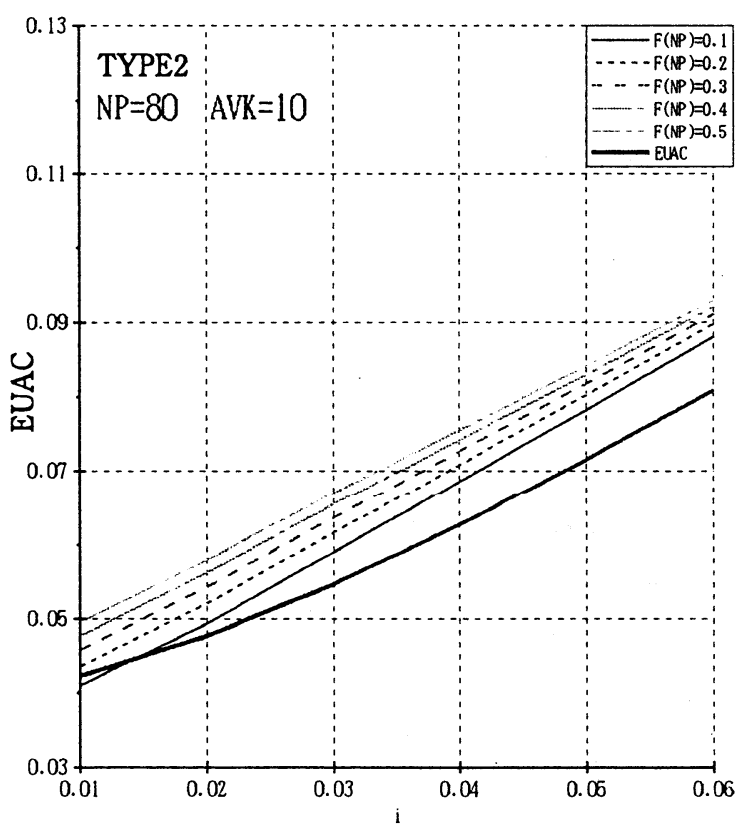

囚-11(e)NP=80 AVK=100䘫合

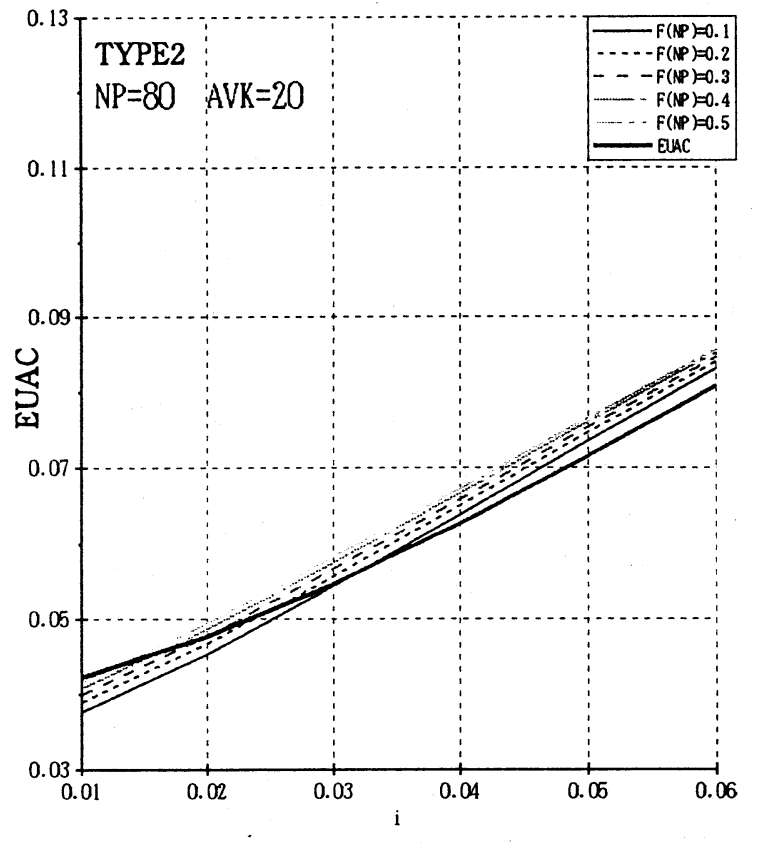

目-11(f) NP=80 AVK=200㛫合

図-11 E U A C と利率の関係：T Y P E 2 の場合

以上の図の結果から次のようなことがいえる。

(1)利率：利率が低いときには補修を行うほうが，利 率が高く見込まれるときには取り替える方が有利 であると思われる。

(2)補修費用：補修費用が増えるにつれて，当然であ

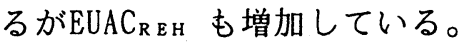

(3)耐用年数：耐用年数が長くなると，EUACRE $\mathrm{C}_{\mathrm{REH}}$ の值はどちらも小さくなり，相対的にEUAC $\mathrm{EEP}_{\mathrm{R}}$ の方が有利といえる。

(4)補修の発生回数 : 補修の発生回数が 20 年に 1 回 程度では拊用年数が長くなるにつれて，EUAC REP $\mathrm{EUAC}_{\mathrm{REH}}$ の差は小さく, 補修費用が多少高い場合 でも,利率が低いという条件で, $\mathrm{EUAC}_{\mathrm{REP}}$ がEUAC $\mathrm{REH}_{\mathrm{R}}$ を上回ることがある。

(5)劣化曲線：TYPE1とTYPE2の橋梁の補修モデルの平 均寿命を比較した結果, TYPE2の劣化モデルの方が やや長くなり経済的にみて有利である。したがっ て、劣化モデルの選択が重要になると考えられる。 
8.あとがき

本研究は, 土木構造物の中でも特に橋梁構造物を モデルとしたライフサイクル・コストの経済性評価 という事に関して, 維持・補修計画の策定を目標と して, シミュレーションを行い, 利率, 補修費用, 耐用年数等の関連から, 年平均均等価格 (EUAC)に基 づいた定性的な評価を実施した。それによると，劣 化関数の評価, および利率の予測の違いがEUACに及 ぼす影響が異なり, 補修した方が経済的になるか, または耐用年数がきたらそのまま廃棄した方が経済 的になるかの方法の選択に与える影響を指摘できた。

しかしながら，4.でも述べたように, シミュレ ーションモデルに用いらている仮定された多くの変 数は定量的な評価が困難でありしたがって現実のモ テルから幾分かけ離れている可能性むある。またモ テル化に対しても補修頻度, 補修費, 劣化状況等の データの裏付けも乏しいという点本研究の限界とな っている。

\section{【参考文献】}

1) 例えば・小林一軸：コンクリート構造物の早期劣 化之耐久性診断診断, 森北出版, 1991.7.

2) 野沢太三 : メンテナンスの経済的側面、土木学会 誌, pp17-21, 1979. 10.

3) 菅原操 : メンテナンスー今後への展望, 土木学会
誌, pp57-62, 1979. 10.

4) 土木構造物の耐用年数、劣化現象としての考え方, 土木学会誌, $\quad$ pp8-19, 1983.10.

5) 坂井順行: 国富および社会資本ストックの推移と 維持管理問題, 土木学会誌, pp. 33-37, 1983. 10.

6) 岩松幸雄, 早川祐史, 原田隆朗 : 道路構造物の維 持管理システムに関する研究, 土木学会論文集, No. 444/VI-16, pp. 69-76, 1992.3.

7) Ross Sandler, Samuel I. Shwarts:Spanning the 21st Centry（上）（下），（三木千尋他訳）, 橋梁と基礎, 89-10.

${ }^{8)}$ 西川和廣：道路橋の寿命と維持管理、土木学会論 文集, No. 501/I-29, pp. 1-10, 1994. 10

9) 例えば 室津義定, 大場史憲, 米沢政昭, 藤井進 : システム工学, 森北出版, pp. 16-29, 1981.2.

${ }^{10)}$ Richardo E Weyers, Philip D Cady, and Richard M. McClure:Cost-Effective Dicision Models for Maintanance, Rehabilitation, and Replacement of Bridges, Transportation Research Record 950, pp. 28-33, 1985.

11) Ken Koyama: Reliability Based Economic Evaluation of Structures Considering the Life Term, Proc. of JSCE No.410/I-12, pp. 1871993, 1989. 10.

12) 例えば 米倉亮三: 社会システム工学入門, 三海 堂, 1990.2.

Economic Evaluation of Life Cycle costs on Brigde Rehabilitation or Meintenance

It seeems really important to make adequate maintemance and rehabilitation management schemes for keeping the existent structures good condition.

In this paper, a simulation method for estimating life cycle cost of bridge is proposed using the Value Management Term whether the bridge shoud be rehabilitated or replaced without maintenance. This is evaluated by EUAC for annual interests, qualitatively. To be replaced or not depends on the type of bridge deterioration or annual interest rates, significantly. 